\title{
FORMULASI DAN UJI ANTI BAKTERI GEL EKSTRAK ETANOL KULIT BAWANG PUTIH (Allium sativum L) TERHADAP BAKTERI Staphylococcus aureus
}

\author{
Michrun Nisa*, Waode Syawal Lastri, Wahyu Hendrarti \\ Sekolah Tinggi Ilmu Farmasi Makassar \\ *Email: mnmichrunnisa84@gmail.com \\ Received: 30/01/2021, Revised: 18/02/2021, Accepted: 25/02/2021, Published: 28/02/2021
}

\begin{abstract}
ABSTRAK
Kulit bawang putih (Allium sativum L) mengandung flavanoid yang berkhasiat sebagai antibakteri. Ekstrak etanol kulit bawang putih menggunakan bahan pembentuk gel carbopol di formulasi dalam bentuk sediaan gel agar efektivitas terapetik serta kenyamanan penggunaan secara topikal dapat tercapai. Penelitian ini bertujuan mengetahui pengaruh variasi konsentrasi basis karbopol gel ekstrak etanol kulit bawang putih terhadap sifat fisik gel dan menguji aktivitas antibakteri terhadap Staphylococcus aureus. Metode maserasi dengan pelarut etanol $70 \%$ merupakan metode ekstraksi yang digunakan.Formula dibuat dalam tiga formula dengan memvariasikan konsentrasi karbopol yaitu 0,5, 0,75 dan $1 \%$. Pengujian sifat fisik yang dilakukan berupa uji organoleptis, homogenitas, viskositas, $\mathrm{pH}$, daya sebar, dan uji daya lekat. Uji aktivitas antibakteri dilakukan menggunakan metode difusi dengan membuat sumuran yang diisi gel pada media agar. Hasil penelitian menunjukkan bahwa semakin tinggi konsentrasi gelling agent karbopol dalam gel, semakin tinggi viskositas dan daya lekat, serta makin rendah daya sebar, namun tidak berpengaruh terhadap homogenitas, organoleptik dan $\mathrm{pH}$. Hasil uji bakteri menunjukkan bahwa pada konsentrasi karbopol 0,5, 0,75 dan $1 \%$. memberikan hambatan sebesar $10 \mathrm{~mm}$ sedangkan kontrol positif memberikan hambatan sebesar $20 \mathrm{~mm}$.
\end{abstract}

Kata kunci :ekstrak,kulit,bawang putih,antibakteri

\begin{abstract}
Garlic skin (Allium sativum L) contains flavonoids which have antibacterial properties. The ethanol extract of garlic peel uses a carbopol gel-forming ingredient in a gel formulation so that therapeutic effectiveness and convenience of topical use can be achieved. This study aims to determine the effect of variations in the base concentration of carbopol gel from ethanol extract of garlic peel on the physical properties of the gel and to test the antibacterial activity against Staphylococcus aureus. The maceration method with $70 \%$ ethanol solvent is the extraction method used. The formula is made in three formulas by varying the concentration of carbopol, namely $0.5,0.75$ and 1\%. The physical properties test were carried out in the form of organoleptic tests, homogeneity, viscosity, $\mathrm{pH}$, dispersion, and adhesion tests. The antibacterial activity test was carried out using the diffusion method by making a well filled gel on agar medium. The results showed that the higher the concentration of the carbopol gelling agent in the gel, the
\end{abstract}


higher the viscosity and adhesion, and the lower the spreadability, but it did not affect homogeneity, organoleptic and $\mathrm{pH}$. The results of the bacterial test showed that the carbopol concentration of 0.5, 0.75 and $1 \%$ gave $10 \mathrm{~mm}$ resistance while the positive control gave $20 \mathrm{~mm}$ resistance Keywords:extract,onion, antibacterial

\section{PENDAHULUAN}

Penggunaan tanaman obat sebagai antibakteri sudah banyak digunakan oleh masyarakat dan telah dilakukan pula penelitian yang membuktikan aktivitas antibakteri, salah satu tanaman yang diduga mempunyai senyawa antibakteri adalah kulit bawang putih (Allium sativum L). Limbah kulit bawang putih hanya dibuang dan belum dimanfaatkan oleh (Rosyid dkk, 2016). Senyawa yang terkandung dalam ekstrak kulit umbi bawang putih yaitu flavonoid, alkaloid, saponin, kuinon dan polifenol. Serta memiliki aktifitas anti bakteri terhadap bakteri Staphylococcus aureus, Escherichia coli dan Proteus vulgaris (Ifesan, 2014). Senyawa flavanoid memiliki aktivitas antibakteri. Mekanisme kerja dari flavanoid dengan mendenaturasi protein yang dimiliki bakteri (Muhammad dkk,2014).

Berbagai bentuk sediaan farmasi dapat digunakan dalam penghantaran obat secara topikal. Bentuk sediaan yang paling banyak digunakan adalah gel, krim dan salep kemudian bentuk sediaan semprot dan cair (Verma dkk,2013). Penghantaran obat secara topikal menggunakan bentuk sediaan gel dapat meningkatkan waktu tinggal dari obat pada tempat pemberian (Karadvozka,2013). Pemilihan basis karbopol karena kemampuan untuk menyerap air akan mengembang dalam air hingga 1.000 kali volume asal dan 10 kali diameter aslinya (Wijayanto,2017). Karbomer tidak mengiritasi pada pemakaian berulang serta akan membentuk gel yang transparan dan bioadhesive (Dewi,2016).

Pada formulasi gel ekstrak kulit bawang putih digunakan karbopol 940 sebagai gelling agent dan TEA (Trietanolamin) sebagai penetral $\mathrm{pH}$ sekaligus sebagai penstabil karbopol 940. Penelitian ini membuat sediaan gel ekstrak kulit bawang putih dengan variasi kadar karbopol 0,5, 0,75 dan $1 \%$, uji aktivitas ekstrak, mengkaji sifat fisik serta mengetahui efektivitas setiap sediaan gel.

\section{METODE PENELITIAN Alat dan Bahan}

Alat-alat yang digunakan adalah wadah maserasi, seperangkat alat rotary evaporator $\left(\right.$ Buchi $\left.^{\circledR}\right)$, timbangan analitik (Chq Mettler Toledo Al 204 $\left.{ }^{\circledR}\right)$, freeze dryer, autoklaf $\left(\right.$ Nuaire $\left.^{()}\right)$, beaker glass $\left(\right.$Pyrex $\left.^{\circledR}\right)$, 
gelas ukur $\left(\right.$ Pyrex $\left.^{\circledR}\right)$, hot plate, incubator $\left(\right.$ Memmert $\left.^{\circledR}\right)$, laminar air flow $\left(\right.$ Robust $\left.^{\circledR}\right)$, micropippet (Dragonmed $\left.{ }^{\circledR}\right), \quad$ viscometer (Brookfield $^{\circledR)}$, pH universal.

Bahan-bahan yang digunakan adalah kulit bawang putih (Allium sativum) yang diperoleh dari pengumpul di pasar daya Makassar, carbopol 940 (quadran $\AA$ ), DMSO, metil paraben (quadran $®$ ), triethanolamin (quadran®), propilenglikol (quadran®), etanol 70\%, bakteri uji Staphylococcus aureus, Nutrient Agar.

\section{Prosedur Penelitian}

Penelitian yang dilakukan adalah penelitian eksperimen skala laboratorium dengan menggunakan analisis deskriptif.

1. Pembuatan ekstrak

Sampel kulit bawang putih (Allium sativum) diperoleh dari pengumpul di pasar daya,Makassar, sampel kemudian disortasi basah,dilakukan perajangan dan dikeringkan dengan cara diangin-anginkan kemudian dilakukan sortasi kering. Sampel di ekstraksi dengan metode maserasi menggunakan pelarut etanol $70 \%$ selama 5 hari. Ekstrak yang diperoleh dikentalkan dengan rotary evaporator dan di freeze dryer.
2. Uji kualitatif kandungan kimia

Uji kandungan kimia terdiri dari dari uji kualitatif senyawa alkaloid menggunakan pereaksi mayer,wagner dan dragendroft. Uji flavonoid dengan penambahan serbuk $\mathrm{Mg}$ dan $\mathrm{HCl}$ pekat, uji tannin dengan penambahan $\mathrm{FeCl}_{3}$, uji terpenoid dan steroid serta uji saponin.

3. Uji Aktivitas Antibakteri Ekstrak terhadap Bakteri Staphylococcus aureus

Metode difusi agar dengan paper disc digunakan untuk menguji Uji aktivitas antibakteri ekstrak etanol kulit bawang putih. Medium NA steril sebanyak $15 \mathrm{~mL}$ secara aseptik dituang ke dalam cawan petri yang berisi suspensi bakteri. Suspensi bakteri Staphylococcus aureus dimasukkan ke dalam cawan petri sebanyak $20 \mu \mathrm{l}$ dan dihomogenkan, lalu biarkan memadat. Kemudian paper disk yang telah ditetesi ekstrak kulit bawang putih dengan konsentrasi 1, 3, dan 5\% yang diperoleh dari penentuan konsentrasi hambat minimum metode turbidimetri dengan menggunakan mikropipet sebanyak $20 \mu$ l. Didiamkan \pm 15 menit, kemudian paper disk secara aseptis diletakkan menggunakan pinset steril di atas permukaan medium dengan jarak 2-3 cm dari pinggir cawan petri. DMSO $10 \%$ 
sebagai kontrol negatif dan paper disk tetrasiklin $30 \mu \mathrm{g}$ sebagai kontrol positif. Selanjutnya dalam inkubator diinkubasi pada suhu $37^{\circ} \mathrm{C}$ selama $1 \times 24$ jam. Zona hambat yang timbul disekitar paper disk selanjutnya diukur diameternya menggunakan jangka sorong.

\section{Formulasi gel}

Formulasi gel ekstrak bawang putih dengan memvariasikan konsentrasi carbopol sebagai gelling agent.

Tabel 1. Rancangan Formula Gel Ekstrak Etanol Kulit Bawang Putih

\begin{tabular}{llll}
\hline Bahan & \multicolumn{3}{c}{ Formula (\%) } \\
\cline { 2 - 4 } & \multicolumn{1}{c}{ F1 } & \multicolumn{1}{c}{ F2 } & \multicolumn{1}{c}{ F3 } \\
\hline Ekstrak & 3 & 3 & 3 \\
Carbopol & 0,5 & 0,75 & 1 \\
Propilenglikol & 10 & 10 & 10 \\
Metil Paraben & 0,2 & 0,2 & 0,2 \\
TEA & qs & qs & qs \\
Aquadest & Ad 100 & Ad 100 & Ad 100 \\
\hline
\end{tabular}

Formula sediaan gel dibuat dengan tiga macam konsentrasi karbopol 940 dengan komposisi seperti pada Tabel 1. Carbopol didispersikan selama semalam dalam air dingin. Ekstrak didispersikan dalam propilengikol. Carbopol yang telah terdispersi diaduk homogen,ditambahkan metil paraben yang sebelumnya telah dilarutkan dalam air 112 panas, kemudian ditambahkan ekstrak,dan diaduk homogen. Ke dalam campuran, ditambahkan air sampai volume $100 \mathrm{~mL}$, kemudian ditambahkan TEA tetes demi tetes sampai terbentuk gel yang jernih.

\section{Uji Stabilitas Fisik Sediaan Gel Ekstrak Etanol Kulit Bawang Putih}

Uji stabilitas fisik sediaan gel meliputi uji homogenitas, organoleptis, uji pH, uji daya sebar, uji daya lekat,uji viskositas.

\section{Uji Daya Hambat Antibakteri Gel Ter- hadap Staphylococcus aureus}

Uji daya hambat menggunakan metode difusi sumuran. Kontrol positif yang digunakan adalah gel mediklin dan kontrol negatif digunakan formula basis gel tanpa ekstrak etanol kulit bawang putih. Setiap sampel diuji dalam 3 replikasi dan diinkubasi selama 1 x 24 jam pada suhu $37^{\circ} \mathrm{C}$. Zona hambat yang timbul disekitar paper disk selanjutnya diukur diameternya menggunakan jangka sorong.

\section{HASIL DAN PEMBAHASAN}

Hasil penelitian dari uji kualitatif kandungan kimia menunjukkan hasil ekstrak etanol kulit bawang putih positif mengandung senyawa golongan alkaloid, flavonoid, tannin, terpenoid dan saponin. 


\section{Uji Aktivitas Antibakteri Ekstrak}

Hasil uji aktivitas antibakteri ekstrak etanol kulit bawang putih pada konsentrasi 1,3 dan 5\% menunjukkan diameter rata-rata penghambatan berada pada kisaran 10-11 mm (tabel 2). Hasil tersebut menunjukkan nilai aktivitas penghambatan yang kuat (Davis,1971). Konsentrasi yang dipilih untuk diformulasi adalah konsentrasi 3\% dengan pertimbangan daya hambat yang besar dengan konsentrasi yang kecil untuk menghasilkan sediaan dengan penampilan fisik yang lebih baik.

Tabel 2. Hasil daya hambat gel ekstrak etanol kulit bawang putih

\begin{tabular}{cc}
\hline Konsentrasi $(\%)$ & Hasil $(\mathrm{mm})$ \\
\hline 1 & 10 \\
3 & 10,9 \\
5 & 11 \\
\hline
\end{tabular}

\section{Uji Stabilitas Fisik Sediaan}

a. Hasil pengamatan organoleptis dan homogenitas

Pengamatan organoleptis meliputi warna,bau dan konsistensi menunjukkan warna gel yang seragam agak kecoklatan sesuai warna ekstrak, bau khas kulit bawang putih, konsistensi menunjukkan peningkatan kekentalan sejalan dengan peningkatan konsentrasi carbopol. Hasil uji homogenitas menunjukkan ketiga formula tidak memperlihatkan adanya partikel kasar. Homogenitas adalah faktor penting untuk menggambarkan bahwa distribusi ekstrak dalam sediaan seragam,tidak terdapatnya partikel kasar dan distribusi warna yang seragam menggambarkan bahwa ekstrak etanol kulit bawang putih terdistribusi merata dalam basis gel.

\section{b. Hasil $\mathrm{pH}$}

Hasil pH menggambarkan apakah gel yang dihasilkan bersifat asam atau basa. $\mathrm{pH}$ sediaan umumnya berada pada kisaran $\mathrm{pH}$ 4,5-6,5 (Tranggono, 2007). Nilai $\mathrm{pH}$ yang kurang dari 4,5 dapat mengiritasi kulit, sementara nilai $\mathrm{pH}$ yang melebihi 6,5 membuat kulit menjadi bersisik.

Tabel 3. Pengaruh konsentrasi carbopol terhadap nilai $\mathrm{pH}$

\begin{tabular}{cc}
\hline Nama Formula & Hasil \\
\hline F1 & 5,30 \\
F2 & 5,32 \\
F3 & 4,90
\end{tabular}

Hasil uji pH menunjukkan bahwa ketiga formula memiliki nilai $\mathrm{pH}$ yang berada pada rentang yang aman digunakan pada kulit. Hasil pengukuran $\mathrm{pH}$ menunjukkan hasil yang berbanding terbalik dengan pening- 
katan konsentrasi carbopol, semakin tinggi konsentrasi carbopol maka nilai $\mathrm{pH}$ makin menurun.

c. Hasil daya lekat dan daya sebar

Pengujian daya sebar untuk melihat kemampuan sediaan menyebar pada kulit. Daya sebar yang semakin besar menunjukkan kemampuan zat aktif untuk menyebar lebih baik. Parameter nilai daya sebar gel yang baik antara $5 \mathrm{~cm}$ hingga $7 \mathrm{~cm}$ (Nurtrisia,2015). Berdasarkan nilai daya sebar yang diperoleh (tabel 4) menunjukkan penurunan daya sebar dengan peningkatan konsentrasi carbopol. Peningkatan jumlah carbopol meningkatkan konsistensi gel sehingga menurunkan konsentrasi daya sebar.

Uji daya lekat gel untuk menggambarkan kemampuan sediaan melekat pada kulit. Semakin lama waktu yang dibutuhkan sediaan untuk melekat pada kulit maka efek yang diinginkan akan semakin baik. Peningkatan konsentrasi carbopol meningkatkan viskositas gel sehingga gel semakin tertahan untuk mengalir pada kulit. Hasil penelitian menunjukkan penurunan daya sebar dan peningkatan daya lekat dengan semakin meningkatnya konsentrasi carbopol.
Tabel 4. Pengaruh carbopol terhadap daya sebar dan lekat sediaan gel

\begin{tabular}{cll}
\hline Nama Formula & $\begin{array}{l}\text { Daya } \\
\text { sebar } \\
(\mathrm{cm})\end{array}$ & $\begin{array}{l}\text { Daya } \\
\text { Lekat } \\
(\mathrm{s})\end{array}$ \\
\hline F1 & 5,3 & 1,55 \\
F2 & 4,5 & 1,72 \\
F3 & 4,3 & 1,89 \\
\hline
\end{tabular}

d. Hasil uji viskositas

Uji viskositas menunjukkan bahwa konsentrasi karbopol yang semakin meningkat maka akan meningkatkan nilai viskositas dari sediaan gel. Matriks penyusun gel mengalami peningkatan karena peningkatan konsentrasi gelling agent.(Astuti, dkk., 2017)

Tabel 5. Pengaruh carbopol terhadap viskositas sediaan gel

\begin{tabular}{cc}
\hline Formula & Nilai Viskositas $(\mathrm{Cp})$ \\
\hline F1 & 6.467 \\
F2 & 32.200 \\
F3 & 38.400 \\
\hline
\end{tabular}

3. Uji daya hambat gel

Gel yang telah diformulasi, dilakukan pengujian daya hambat. Berdasarkan hasil tabel 6 bahwa ketiga formula gel ekstrak etanol kulit bawang putih dengan variasi konsentrasi carbopol memiliki aktivitas ter- 
hadap bakteri $S$. aureus ditandai dengan adanya zona hambat .

Tabel 6. Hasil daya hambat gel ekstrak etanol kulit bawang putih

\begin{tabular}{cc}
\hline Nama Formula & Hasil $(\mathrm{mm})$ \\
\hline F1 & 10,20 \\
F2 & 10,70 \\
F3 & 10,8 \\
\hline
\end{tabular}

Hasil pada tabel 6 menunjukkan nilai daya hambat formula gel pada kisaran angka $10 \mathrm{~mm}$, sedang basis masing-masing konsentrasi carbopol tidak memberikan penghambatan. Menurut nilai persyaratan zona hambat dinyatakan sedang. Zona hambat dikategorikan $<5 \mathrm{~mm}$ lemah, 6-10 $\mathrm{mm}$ sedang, 11-20 kuat dan > 20 sangat kuat. (Yuliana,2021). Tidak terdapat pengaruh konsentrasi carbopol terhadap peningkatan daya hambat gel ekstrak etanol kulit bawang putih. Zona daya hambat yang terbentuk pada sekeliling paper disc karena kandungan metabolit sekunder pada ekstrak etanol kulit bawang putih yang terdapat didalam basis gel, memiliki khasiat antibakteri yang cukup untuk menghambat bakteri S.aureus.

\section{KESIMPULAN}

Konsentrasi gelling agent karbopol yang semakin tinggi dalam gel meningkatkan nilai viskositas dan daya lekat, serta penurunan daya sebar namun tidak berpengaruh terhadap homogenitas, organoleptik dan $\mathrm{pH}$.

Hasil uji aktivitas pada gel dengan variasi konsentrasi carbopol menunjukkan nilai daya hambat yang sama yaitu $10 \mathrm{~mm}$.

\section{DAFTAR PUSTAKA}

Astuti Puji Dwi, Husni Patihul, Hartono Kusdi. (2017). Formulasi Dan Uji Stabilitas Fisik Sediaan Gel Antiseptik Tangan Minyak Atsiri Bunga Lavender (Lavandula angustifolia Miller). Jurnal Farmaka,15,(1),176184.

Davis, W. W. dan T. R. Stout. 1971. Disc plate methods of microbiological antibiotic assay. Microbiology, 22, 659665 .

Dewi CC, Saptarini NM. (2016). Hidroksi Propil Metil Selulosa dan Karbomer Serta Sifat Fisikokimianya Sebagai Gelling Agent. Jurnal Farmaka, 14,(3),1-13.

Ifesan B. (2014).Investigation of Antioxidant and Antimicrobial 
Properties of Garlic Peel Extract (Allium sativum) and Its Use as Natural Food Additive in Cooked Beef. J Sci Res Reports,3,(5),711-721. Karadzovska, D., Brooks, JD., MonteiroRiviere ,NA., Riviere, JE.(2013). Predicting skin permeability from complex vehicles. Advanced Drug Delivery Reviews, 65(2).

Muhammad,G.,Muammad,I.,Sobia,K.,

Dawood, A., Muhammad JA, Kashis SA, et al. (2014) A comparative study of antimicrobial and antioxidant activities of garlic (Allium sativum.) extracts in various localities of Pakistan. African $J$ Plant Sci,8(6),298-306.

Tranggono RI., Latifah, F. (2007). Buku Pegangan Ilmu Pengetahuan

Kosmetik. Jakarta : Gramedia Pustaka Utama.

Verma,A., Singh,S., Kaur,R., Kumar,A., Jain,UK.(2013)Formulation,

optimization and evaluation of clobetasol propionate gel. Int $J$ Pharm Pharm Sci,6,(5),15-18.

Wijayanto,BAJI., Kurniawan,DW., Sobri, I.(2017) Pengembangan Produk Sediaan Gel Kombinasi Ekstrak Daun
Sirsak (Annona Muricita L.) Dengan Ekstrak Rimpang Temulawak (Curcuma Xanthorhiza Roxb.) Sebagai Anti Bakteri Penyebab Jerawat (Propionibacterium Acne Dan Staphylococcus Epidermidis). Pharmacon, 6,(4),255-265.

Yuliana, A., Rofi, U. M., Fathurohman, M., \&Rahmawati, L. (2021). UjiAktivitas Larutan InfusaTeh (CameliaSinensis (L.,) Kuntze) Dengan Penambahan Bawang Putih (Allium Sativum L) Terhadap Bakteri Shigella dysenteriae. Journal of Pharmacopolium, 3(3) 